\title{
PROPOSED IMPROVEMENT OF THE IOWA STATE CAPITOL GROUNDS.
}

\author{
BY EDGAR R. HARLAN.
}

[This matter was prepared as an address to be read to the Iowa Chapter American Institute of Architects, at its session in the Historical Building, October 22, 1913.]

It is a part of the business of the Historical Department of Iowa to co-operate and exchange thought with every other Iowa person and institution standing for true culture. In that service it has exchanged courtesies with creators as well as lovers of painting, sculpture, literature, and all the other arts. It is with peculiar satisfaction and appropriateness that the opportunity is accepted today, of exchanging thought with your society as our guests.

The Curator of the Historical Department of Iowa began early in his service with the Allison Memorial Commission (a duty conferred upon him by statute ${ }^{1}$ ) to confer with mem-

'LAWS OF IOWA, THIRTY-THIRD GENERAL ASSEMBLY, 1909, CHAPTER 251.

PEDESTAL FOR A MONUMENT TO BE ERECTED IN MEMORY OF WILLIAM B. ALLISON.

AN ACr to create a commission authorized to locate and erect a pedestal for a monument to the memory of the late William B. Allison and for a me expense thereof.

making an appropriation to defray have undertaken to create by public Whereas, certain parion of a monument at the subscription a city of Des Mo

Whereas, It is necessary to provide a pedestal for said monument and a site for the same, therefore

Be it enacted by the General Assembly of the State of Iova:

Section 1. Commission-how constituted. A commission of five persons, to consist of the chairman of the Allison monument committee, persons, to cor the state of Iowa, the curator of the historical collections, a member of the senate, to be named by the president of the senate, and a member of the senate, of representatives, to be named by the speaker a member of the house of representatives, purpose of erecting a suitable of the house, is hereby created for the munument to the memory of the

late William B. Allison. Said commission is hereby clothed with full authorSec. 2. Powers. ity to locate and erect upon the by the Allison monument committee in a suitable pedestal monument to the memory of the late William $\mathbf{B}$. erecting thereon a monument shall have authority to do all things Allison, and such commission shall have authorition of such pedestal, reasonable and necessary to the location and erection of such pedission; 


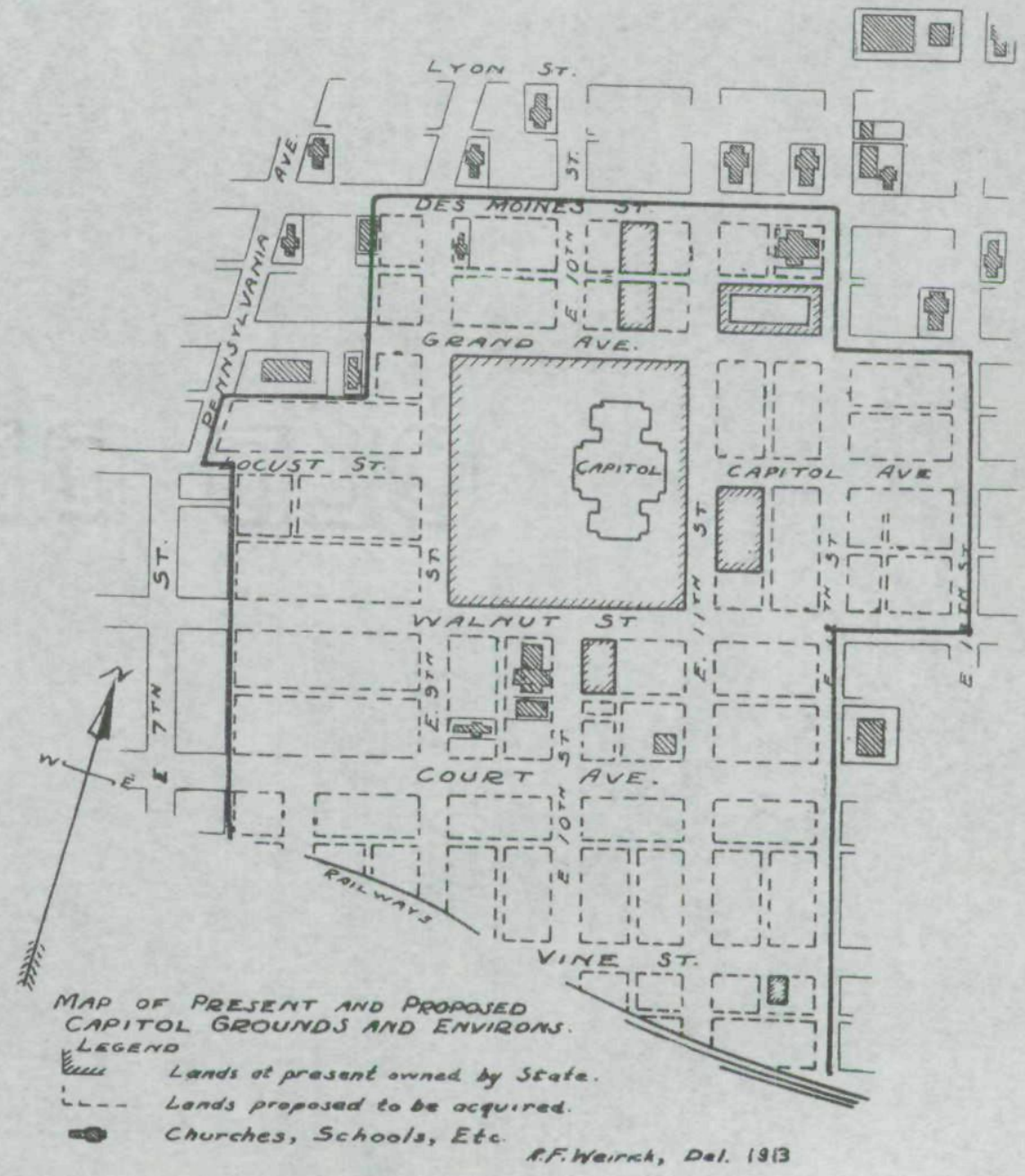

Outline map of present and proposed Iowa State Capitol grounds and environs, Des Moines, Iowa. 
bers of your profession in Des Moines and other cities, with a view to fully fortifying his judgment along architectural lines. He thus arrived for the first time at a full comprehension of the ability of his associates on the Commission, and of their perception that their duty was not only to avoid mistake, but also to embrace a really magnificent opportunity; that is, while commemorating in sculpture, Iowa's great statesman, the Commission could and should in the selection of a site lead the State from an aimless policy of random placement of its State buildings, out upon the broad, sensible ground of regular, permanent, artistic arrangement. This would at once be a further tribute to the memory of Senator Allison $^{2}$ and a monument to the business ability of his generation.

The law ereating the Commission provided that the memorial should be placed "upon the capitol grounds or some extension thereof." Your trained minds instantly perceive that however well the sculptor may say in plastic language, "This

provided, however, that said commission shall not expend in the erection of such pedestal a sum in excess of thirty $(30 \%)$ per cent of the amount of the popular subscription made for the erection of said monument, and in no event shall said commission expend to exceed ten thousand $(\$ 10,-$ $000.00)$ dollars.

Sec. 3. To serve without compensation-expenses. Said commission shall serve without compensation and shall be allowed only its actual expenses reasonably incurred while engaged in the discharge of its duties. Sec. 4. Appropriation-how drawn. There is hereby appropriated from the funds in the state treasury not otherwise appropriated the sum of ten thousand dollars $(\$ 10,000.00)$ or so much thereof as may be necessary to defray the authorized expense of erecting said pedestal and of said commission. The auditor of state is authorized to draw warrants against said appropriation upon the certificate of said commission showing that the several sums have, in good faith, been expended in the erection of said pedestal or in paying the necessary expenses of said commission. sec. 5 . In effect. This act being deemed of immediate importance shall take effect and be in force from and after its publication in the Register and Leader and the Des Moines Capital, newspapers published in the eity of Des Moines, Iowa.

Approved, February 23, A. D. 1909.

"WTIAM BoyD AUtron was born in Wayne county, Ohio, March 2, 1829. He received his early education at Allegheny College, Meadville, Pa., and Western Reserve College, Ohio. He took up the study of law, was admitted to the bar in 1850 and practiced in Ohio for seven years. Immediately upon his removal to Dubuque, Iowa, in 1857, he became an active and influential factor in Iowa politics. He served as delegate to the Republican State Convention in 1859 and to the National Convention that nominated Lincoln at Chicago in 1860 . He was a member of the Governor's staff and aided in raising troops for the Civil War. He was elected Representative in Congress in 1863 and served until 1871. In 1873 he was elected United States Senator and was a member of that body continuously until his death, giving effective service as member and chairman of the appropriations committee and member of the finance committee. He was chairman of the National Monetary Conference at Brussels in 1892. He declined Cabinet positions offered him by Presidents Garfield, Harrison and McKinley. He was a candidate for presidential nomination at the National Republican Conventions of 1888 and 1896 He died at his home in Dubuque, August 4, 1908. 
was one of the great American minds," our indifference as to where the work shall stand will say, "But it was a shortsighted generation in which that famous statesman elosed his fruitful life."

And so it was that the chairman of this Commission, Gen. Grenville M. Dodge, one of the great builders of America, instantly approved the scheme of having the expert committee of trained men which had been invited to assist in the selection of the model, also advise upon the selection of the site. The National Seulpture Society, which delegated this committee, assigned to us, as sculptor expert, Mr. Karl Bitter", and as architect expert, Mr. E. L. Masqueray ${ }^{5}$. But the day

"Grenvilue Merlen Dodge was born at Danvers, Mass, April 12, 1831. He attended Norwich University in Vermont and graduated in 1850 with the degree of $\mathrm{C}$. E. The next year he graduated from Captain Partridge's Military Academy. In 1871 he was employed by the Illinois Central Railway and the next year by the Chicago \& Rock Island Railway, and was assistant engineer during the construction of the Mississippi \& Missouri Railway across the State of Iowa. He was a member of a government survey along the Platte for a railway to the Pacific, one of the first surveys to be instituted for that purpose. He fought through the Civil war and rose to the rank of Major-General of U. S. Volunteers. He was chief engineer of the Union Pacific Railway, 1866 to 1870 , and of the Texas and Pacific Railway, 1871 to 1881 . From 1867 to 1869 he served as member of congress from the Second Iowa District. In 1898 he was made president of the commission appointed to investigate the charges of mismanagement relative to the Spanish-American war. In addition to his interest in the Allison Monument Commission, General Dodge has been connected with many movements for perpetuating the memories of famous Americans. He was vice-president of the trustees in charge of the erection of the Grant monument, New York, and marshal of the day at its dedication, April 27, 1897 ; chairman of the committee from the Society of the Army of the Tennessee which obtained the appropriation and erected the Grant monument, Washington; chairman of the Sherman monument committee and commission, Washington: member of the committee in charge of the Logan monument. Washington; chairman of the committees in charge of the erection of the Lincoln and W. H. Kinsman monuments, Council Bluffs. He personally erected a monument to James Bridger at Kansas City and to Marshall F. Hurd at Denver. He has placed in West Point Memorial Hall a portrait of Maj. Gen. H. W. Halleck, one of Maj. Gen. J. B. MePherson and a bronze tablet commemorating the service of West Point men in the army. General Dodge was the representative of the Government to whom was assigned the duty of accepting the Iowa monuments placed in the national military parks at Shiloh, Vicksburg and Chattanooga.

'KARL THEODORE Francis BITTER, sculptor, was born in Vienna, Austria, December 6, 1867, and was educated in the gymnasium there. He studied art in the Vienna Academy of Fine Arts, and came to the United States in 1889 and was employed in architectural sculpture.

He won a prize in the competition for the Astor memorial gates, Trinity church, New York, and executed sculpture on the administration and manufactures buildings of the Chicago exposition and for the residences of C. P. Huntington, Cornelius Vanderbilt, and others.

He obtained a silver medal at the Paris exposition, 1900, and gold medals at the Buffalo exposition, 1901, Philadelphia, 1902, and St. Louis exposition, 1904. He became a National Academician, 1902 . $\mathrm{He}$ is a member of the National Institute of Arts and Letters and of the National Sculpture Society.

5EMmaNuel Louis Masqueray, architect, was born in Dieppe, France, September, 1861. He was educated at the Ecole des Beaux Arts, Paris, France, and received the Deschaume prize, 1879. Chaudesaigues prize, 1880 , and a gold medal at the Salon, 1883. Mr. Masqueray came to 
for the competition falling on the day of a previous engagement of Mr. Bitter, he yielded to Mr. Charles Grafly', head of the sculpture department of the Pennsylvania Society of Fine Arts. So in the place of Mr. Bitter, Mr. Grafly came to Des Moines, and with Mr. Masqueray, Governor Carroll, General Dodge and the Secretary, under the provisions of the statute began the service of selecting the model and determining the site $^{7}$. Membership on the Commission from the Senate and House had expired, and vacancies remained until the convening of the Thirty-fifth General Assembly.

Mr. Masqueray led in the study of the placement of the memorial; with your speaker he visited the Capitol and all the grounds, streets, and alleys within a reasonable radius. We consulted General Dodge, Governor Carroll ${ }^{8 \mathrm{a}}$, Secretary

America in 1887, locating in New York. He was chief of design at the St. Louis exposition, 1904, erecting there the Cascades, Colonnade of States and Pavilions, Transportation, Agriculture. Horticulture, Fisheries and Forestry buildings: also Louisiana Purchase monument and twelve bridges. He has also erected many important structures in various parts of the country, including Long Island College Hospital, Brooklyn, Cathedral of St. Paul, Pro-Cathedral of Minneapolis and a cathedral at Wichita, Kansas. He is at present erecting Archbishop Ireland's great cathedral at St. Paul. He is a charter member of the Society Beaux Arts Architects, and also a member of the Architectural League, New York, and of the American Institute of Architects.

CHARLES GRAFLY, sculptor, was born at Philadelphia, December 3, 1862. He was a pupil of the Philadelphia Academy of Fine Arts and of Chapu and Dampt, Paris. He received honorable mention Salon of 1891; Temple Trust Fund, Philadelphia, 1892; medal at the Chicago Exposition, 1893 ; silver medal, Atlanta Exposition, 1895 ; Converse gold medal, Pennsylvania Academy of Fine Arts, 1899: gold medal, Paris Exposition, 1900; Charleston Exposition, 1901; Buffalo Exposition, 1901. He was a member of the International Jury of Awards, St. Louis Exposition, 1904, and has been instructor in the Pennsylvania Academy of Fine Arts since 1892. Mr. Grafly is represented in the permanent collections of the Pennsylvania Academy of Fine Arts, Detroit Art Museum, St. Louis Museum and is a member of the National Institute Arts and Letters, National Sculpture Society and Philadelphia Art Club. He has done much notable work in busts, life size and colossal figures and portraits and ideal figures in groups, largely in bronze.

7As a monument should be designed to fit its surroundings, it is important that before preparing the programme, the exact site or location of the proposed work should be determined upon, and that the promoters of the competition should be ready to supply competitors with plan and photographs of the site. The placing of a monument is a matter of the greatest moment, and to select the best site is more difficult than is generally supposed. It is a matter upon which the committee should secure expert advice. ${ }^{*} *^{*}$ The Society, while not assuming to dictate the owner's course in conducting competitions, entertains definite convictions as to the conduct of its own members, and in its by-laws has declared that it is unprofessional conduct for a sculptor to take part in any competition the terms of which are not in harmony with the principles approved by the Society as stated in its Suggestions Relative to Competitions for Sculpture.-Suggestions for Sculptural Competitions by National Sculpture Society.

sa BERYL F. CARROLL Was born in Davis county, Iowa, March 15, 1860. He graduated from the Missouri State Normal, Kirksville, Missouri, in 1884 , and received the degree of LL.D. from Simpson college in 1909 . $\mathrm{He}$ was editor of the Davis County Republican from 1891 to 1902 . He was Republican candidate for Iowa House of Representatives, 1893 ; member of Iowa Senate, $1895-8$ (resigned); postmaster of Bloomfield, Iowa, 1898-1902; state auditor of Iowa, three terms, 1903-09; governor of Iowa, 1909 to 1913. 
of State Hayward ${ }^{\mathrm{sb}}$, State Auditor Bleakly ${ }^{\mathrm{se}}$, State Treasurer Morrow $^{\text {on }}$, Secretary Davison ${ }^{10 \mathrm{a}}$ of the Executive Council and many others with reference to the immediate and eventual need of other structures.

We searched pertinent resolutions and bills introduced into the different legislatures; we read reports of departments for ten years or more and ascertained the present and proposed improvements of like nature in other states ${ }^{\mathrm{I}}$; we examined all

SbWILLAM C. HAYWARD was born in Cattaraugus county, New York, November 22, 1847. He removed to Winnebago county, Iowa, in 1867 . He taught school for several terms and entered the Iowa State College of Agriculture and Mechanic Arts as a member of its first class. He returned to Winnebago county, was elected county surveyor and purchased a half interest in the Winnebago Press. In 1873 he removed to Garner, purchased the Hancock Signal, and served as postmaster for eleven years. He was one of the organizers of the City Bank of Garner and its cashier He later engaged with William Finch in the grain, coal and stock business, operating twenty-five stations in Iowa, Minnesota and South Dakota. The headquarters of the firm were removed to Davenport in 1886 and $\mathrm{Mr}$. Hayward removed to that city. He was president of the Union Savings Bank of Davenport, president of the Davenport National Bank, and a member of the Davenport school board for nine years. He was elected State Senator in 1897 and served through the Twenty-seventh, Twentyeighth, Twenty-ninth, Thirtieth and Thirty-first General Assemblies. In 1906 he was elected Secretary of State and held that office for three terms.

seJoHN L. BLFAKLY was born in County Fermanagh, Ireland, February 17. 1857. He emigrated with his parents to the United States in 1863 , settling in Illinois and removing to Linn county, Iowa, in 1872 . He was educated in the public schools of Illinois and Iowa and the Cedar Rapids Business College. After teaching for several years he engaged in the banking business and later in the mercantile business in Ida Grove. In 1903 he was elected State Senator from the forty-sixth district and served in the Thirtieth, Thirty-first, Thirty-second and Thirty-second Extra General Assemblies. He was elected Auditor of State in 1908 and re-elected in 1910 and 1912 .

aa WrilsoN W. Morrow was born in Guernsey county, Ohio, January 4, 1850. He removed with his father's family in August, is64, to Iowa, and located near Afton, in Union county. The land upon which the family settled in 1864 is a part of the farm now owned by Mr. Morrow. He was educated in the public schools of Afton and graduated from the high school. Mr. Morrow represented Union county in the Twenty-third and Twenty-fourth General Assemblies and was a member of the board of directors of the State Fair Association for eight years, serving one year as vice president. He was state treasurer from 1906 to 1912.

10AARTHUR HENRY DAVISON was born in Blooming Valley, Crawford county, Pennsylvania, March 6, 1857. He attended the public schools of that county and graduated with the degree of Bachelor of Didactics from the Pennsylvania State Normal School at Edinboro. He removed to Lyon county, Iowa, and engaged in school teaching and the real estate business. He served as county superintendent of schools of Lyon county. For eleven years he was a director and for several years chairman of the board of directors of the Rock Rapids schools. In 1893 he was elected to the Iowa House of Representatives from Lyon and O'Brien counties and served through the Twenty-fifth General Assembly. Mr. Davison was appointed Secretary of the Executive Council of Iowa in January, 1899 , continuing in that office to the present time.

${ }^{11}$ Buenos Aires, city plan, removing 40 squares...........\$200,000,000 India, city plan, new civic center. . . . . . . . . . . . . . . . . . $\$ 20,50,000,000$ San Francisco, city plan, architect awarded for design........ 25,000

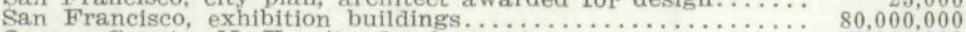

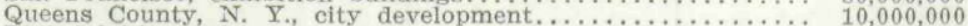
Philadelphia parkway system. . . . . . . . . . . . . . . . . . . . . . $10.2,000,000$ Madison, Wis., city plan and capitoi. . . . . . . . . . . . . . . . . . $5,000,000$ Texas, Steel City, Schwab interests. . . . . . . . . . . . . . . . . . . . . . $5.5,000,000$

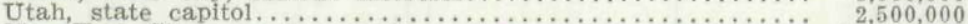

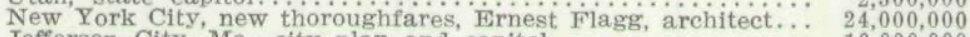
Jefferson City, Mo., city plan and capitol. ................ $10,000,000$ - Abstract from six months' file of the American Contractor, in letter of J. Devereux York. 
the Executive Messages, and took special notice of those of Governors Larrabee ${ }^{12}$, Shaw ${ }^{18}$, Cummins ${ }^{14}$, Garst ${ }^{15}$, Carroll and Clarke $^{10}$. There is probably no better way of tracing cur-

${ }^{12}$ WILLIAM LARRABeE was born in Ledyard, Connecticut, January 20 , 1832. He received a common school education in Connecticut and spent two months in a private academy; came to Iowa in 1853 ; taught school in Hardin, Allamakee county, for a time and worked on a farm for three years. In 1856 he engaged in the milling business in Clermont and continued until 1873 , when he sold his milling business and spent three months in Europe. On his return he engaged in banking and farming and continued in the enlargement of his interests in Iowa banks and Iowa farms throughout his life. He was one of the arbiters which appraised the property of the Green Bay and Mississippi Canal company preparatory to its transfer to the United States government. In 1867 Mr. Larrabee was elected to the State Senate and was four times thereafter nominated by acclamation. In 1885 he was elected governor and his administration was marked by the influence he exerted on legislation, especially along the lines of railroad regulation and the suppression of intemperance. Larrabee's "Railroad Question" is considered an authority. When the legislature passed the Board of Control law, Governor Larrabee was selected for chairman of the board. He was chairman of the executive committee of the Iowa commission of the Louisiana Purchase Exposition at St. Louis. He died at Clermont, Fayette county, Iowa, November $16,1912$.

${ }^{13}$ LesLife MoRtren SHAw was born in Morristown, Vermont, November 2, 1848. He received his early education in the common schools and academy in Vermont. He moved to Iowa in 1869 and in 1874 graduated from Cornell college, Mt, Vernon, Iowa. In 1876 he graduated from the Iowa College of Law, located in Denison and combined the practice of law with an extensive loan business. He was elected governor of Iowa on the Republican ticket in 1897, and served for two terms. He was chairman of the sound money convention which convened in Indianapolis in 1898. At the expiration of his second term as governor, in 1902, he was appointed secretary of the treasury by President Roosevelt and held that position until 1907.

${ }^{14}$ ALBERT BAIRD CUMMINS was born at Carmichaels, Pennsylvania, February 15,1850 . He was educated in the academy of Waynesburg, Pennsylvania, and received the degree of LL.D. at Waynesburg college in 1903 and at Cornell college, Iowa, in 1904. Mr. Cummins studied surveying and became assistant chief engineer of the Cincinnati, Richmond and Fort Wayne R. R. He studied law in the offices of McClellan and Hodges, Chicago. He was admitted to the Illinois bar in 1875 and practiced in Chicago from 1875 until 1878, when he removed to Des Moines, Iowa was a member of the Iowa House of Representatives, 1888 ; presidential elector-at-large, 1892 ; candidate for United States senator, 1894 and 1900 . chairman of the Republican state convention, 1892 and $1896 ;$ member of the Republican National Committee, 1896-1900; delegate to the Republican National conventions, $1892,1896,1900,1904$; governor of Iowa from 1902 to 1908 ; elected United States senator November 24, 1908, for unexpired term (expiring March 3, 1909), of Senator Allison, deceased; re-elected for term, $1909-15$.

${ }^{15}$ WARren GARST was born at Dayton, Ohio, December 4, 1850. He removed to Illinois with his parents in 1858, and in 1859 he established himself in business at Boone, Iowa, later going to Coon Rapids, Carroll county, where he and his brother opened a general merchandise store. To this business Mr. Garst has devoted himself for years. In addition to this he has been interested in farming and banking. He served during the Twenty-fifth, Twenty-sixth, Twenty-sixth Extra, Twenty-seventh, Twenty-eighth, Twenty-ninth, Thirtieth and Thirty-first General Assemblies. He assumed the office of Lieutenant governor on January 17, 1907, and became Governor on November 25, 1908, on the election of Governor Cummins to the United States Senate.

${ }^{16}$ George W. Crarke was born in Shelby eounty. Indiana, October 24, 1852. He removed with his parents to Davis county. Iowa, in 1856 , and worked on a farm until manhood. He taught school twelve months and graduated from Oskaloosa college in 1877, and from the law department of the State University of Iowa in 1878. Immediately upon his graduation he began the practice of law in Adel and continued in this profession until his election as governor in 1912. He was a member of the House of Representatives in the Twenty-eighth, Twenty-ninth, Thirtieth and Thirty-first General Assemblies and was speaker in the Thirtieth and Thirty-first General Assemblies. Mr. Clarke was elected lieutenant-governor in 1908 and re-elected in 1910 . On January 17, 1913, he became Governor of Iowa. 
rents of popular thought. State pride is revealed, shorteomings are stated and remedies suggested, limitations are defined and ways and means outlined. The subject of correcting and completing the Capitol equipment as a part of State policy is usually expressly advocated. Even at the time the removal of the capital from Iowa City and the construction of the Capitol were bitter political issues, no Chief Executive ever stood against providing that the future might build as it needed. In the evolution of the plan to correct and complete the Capitol grounds, the following Executive expressions have had their weight:

Wirtiam Larrabee, Second Biennial Message, February 13, 1890.

The improvement of the capitol grounds ought to be begun at an early day. The grounds should be in keeping with the capitol, which is one of the most beautiful on the continent. The expense of properly laying out the grounds was estimated by the board of capitol commissioners at $\$ 130,786.11$. Since that estimate was made some grading has been done without expense to the State. The sum of $\$ 125,000$ would probably be sufficient to complete this work. The custodian recommends that $\$ 50,000$ per annum be appropriated for three years for the work on the grounds and the interior of the building.

Leslie M. SHaw, First Biennial Message, January 8, 1900.

When the present capitol was built it was believed to be as commodious as the needs of the State would ever require. It has now been occupied sixteen years, and several of the departments are seriously congested. An arsenal is needed for the accommodation of the Adjutant-General's department. Storage of quartermaster supplies is now provided in a building rented for the purpose. It was found necessary to locate the board of control in committee rooms back of the senate chamber, which cannot well be spared from their designed use during session of the General Assembly. A warehouse for the storage and proper distribution of and reshipment of supplies for the various institutions under the management of the Board of Control is much needed and should be provided for at an early date. A new building for the memorial, historical and art department has been erected, and partitions and changes in various offices have been found imperative to make room for the several departments connected with the State government. Evidently additional buildings will be needed in the near future, and these, when erected, should be fireproof, and of substantial and presentable architecture, and should be so located as to improve and add dignity to the present capitol. 
I recommend that the two blocks directly north of the capitol grounds be immediately purchased, or obtained under condemnation proceedings. Nothing will be saved by delay, and the erection of substantial buildings by the owners upon this property may materially add to the expense. Location of public buildings is a matter of prime importance, and I think it will be conceded that these two blocks are very desirable. No location is too good for Iowa, and none but the best should be considered.

Albert B. Cummis, Biennial Message, January, 1906.

In accordance with an act of the Thirtieth General Assembly, the Executive Council sold State Square for $\$ 8,500$. The authority so to do was accompanied with a direction to invest the proceeds of the sale in lots fronting upon Capitol Square. The Council has purchased one lot fronting on Eleventh St., between Capitol Ave. and Walnut, for $\$ 2,250$. It has endeavored to purchase other property, but has hitherto been unable to agree with the owners upon a price.

WARREN GARST, Biennial Message, January 12, 1909.

I feel that you and all the people of the State ought to be deeply interested in the matter of providing a suitable setting for our magnificent State Capitol. It stands today a monument to the good judgment of those who planned it and provided for its creation, and to the faithfulness and integrity of the self-sacrificing men who devoted the best of their lives to its building. Iowa can never pay its debt to Finkbine, Dey, Foote, Wright, Foreman and others of the Capitol Commission. They did their full duty; and partly in their honor and partly that we may complete what they so well begun, it seems to me there is an obligation upon this generation that we make the surroundings and approach to this great structure comport with its dignity and architectural beauty. We have provided in part for the interior decoration; we have neglected the exterior and environment. I would recommend, therefore, a commission authorized to purchase land adjacent to the capitol grounds, with the right of condemnation where necessary, and with funds sufficient to secure such land as may be deemed necessary to provide a beautiful boulevard of approach and surroundings. An appropriation of $\$ 150,000$ would probably suffice.

In making this recommendation I realize that there are those among you who may feel I have gone far out of my way; but I would call your attention to the fact that a very large part of the total cost of the present Capitol represents ornamentation. We ought to make the building and its surroundings beautiful. We ought to make the whole an object of pride to all our people, something that will be an inspiration to better eitizenship and that will give Iowa higher standing in the family of states. I feel so deeply 
upon this question, I am loath to leave it for the more practical matters, but I have full faith that after mature consideration you will see your way clear to provide for this commission.

Beryl F. CARRoLl, Biennial Message, January 14, 1913.

A comprehensive scheme for enlarging the Capitol grounds should be adopted by you and plans be made for the eventual acquiring of the lands to be added to the present holdings of the State. I would recommend that the State buy all the grounds lying between East Ninth and East Twelfth Streets, beginning at Capitol Avenue and extending to the railroad tracks at the foot of the hill to the south. The grounds thus acquired, lying south of Walnut Street, should be parked and beautified, and upon them should be placed the Allison monument and such other monuments as may be erected in the future, and when the State shall build an Executive Mansion, it should be placed upon the high point of ground to the southeast of the Capitol building. Upon the block immediately east of the State House and south of Capitol Avenue should be located a judicial building. I would also suggest that when the time comes that it is necessary to make any considerable improvement in the State's power plant, it would be wise to consider moving it to the foot of the hill, south and southwest of the State House, where it could be reached by a switch, thereby saving the large amount of money that is annually paid for hauling coal with teams and wagons, and also getting rid of the dirt and smoke and the somewhat unsightly appearance of a heating plant immediately in front of the Capitol building.

In suggesting the enlargement of the Capitol Grounds, I wish to say that the owners of some of the lots included in that which I have referred to, have already expressed a willingness to sell the same and some have submitted a price for their holdings. I want also to say that at two or three different times efforts have been made to secure a change of grade in some of the streets about the State House, which change would have a very material effect upon the surroundings if additional lands are to be acquired. The Council has each time objected to these changes and asked the parties interested therein to wait and take the matter up with you with a view to securing co-operation with the City of Des Moines and the State in some general plan of improving the State House surroundings, and I recommend the appointment by you of a committee to take this matter into consideration and co-operate with the officials of the city to the end suggested.

In my opinion the State might profitably dispose of Governor's Square, allowing the city to purchase it for a park if so desired, and invest the proceeds in lands above suggested for purchase. 


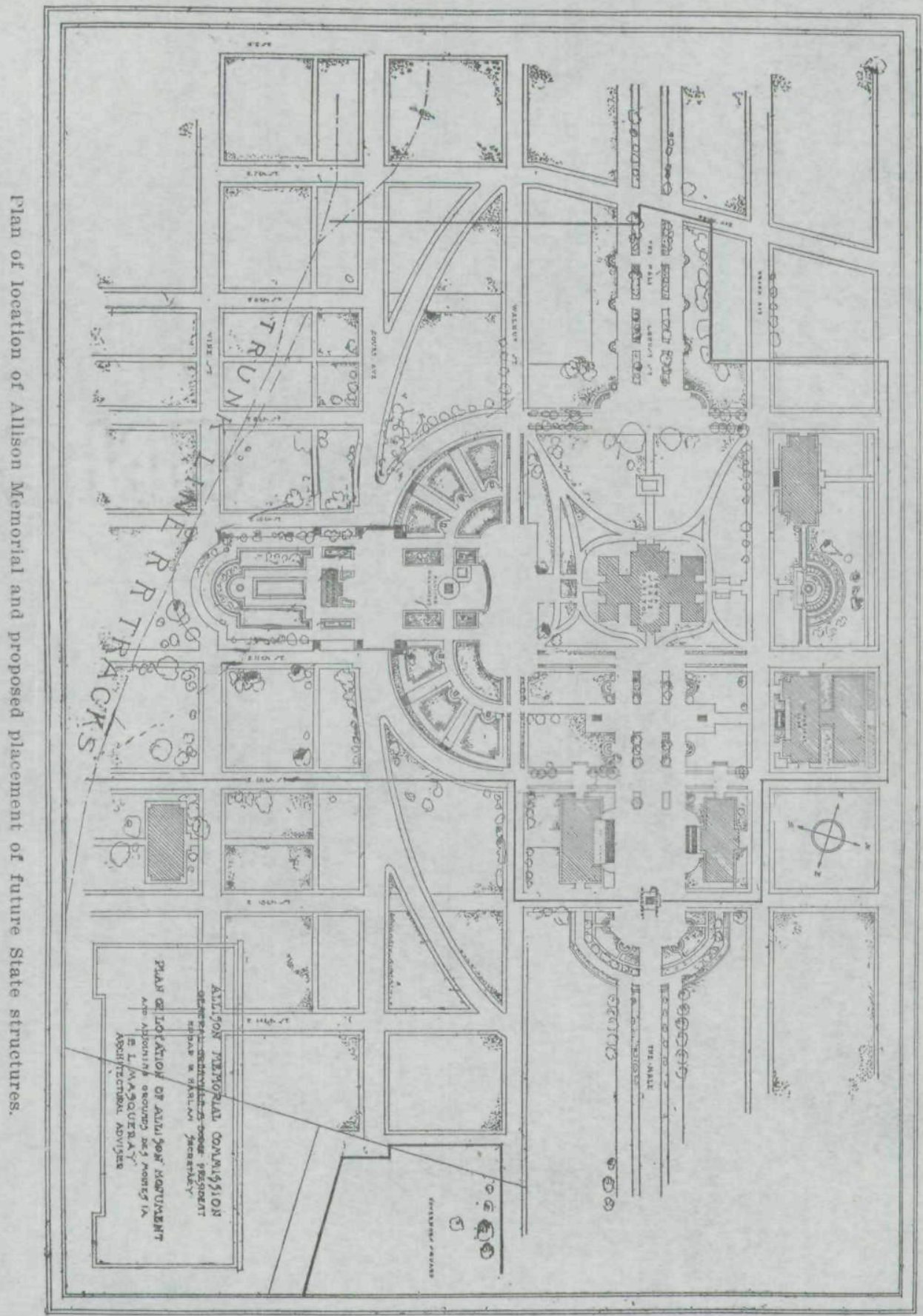


George W. Clakke, Inaugural Address, January 16, 1913.

The subject of the extension of the Capitol Grounds is a matter that should have consideration. The day is now here when these grounds surrounding us should be more spacious and they should be made more beautiful. They do not meet the material demands of the present and for the future they will be entirely inadequate. The future should ever be in mind. We build for those who are to come after us. We should have a vision of what Iowa is to do and be. In the extension of the grounds regard should be had for a better setting of the Capitol. The whole question of the enlargement and location of buildings and monuments should at once be placed in the hands of the best landscape artist that could be found with instructions to prepare a plan commensurate with the needs and ideals of a great, progressive and cultured people. It cannot all be done at once, but a beginning can be made. Every day of postponement only makes the realization more expensive and difficult. What is done should be in accordance with a plan to end in both utility and great artistic beauty.

George W. Clarke, Special Message, March 26, 1913.

I desire to submit a word with reference to the extension of the Capitol Grounds. It is the need of the present-it is the imperative demand of the future. It is a matter of the very best business policy. If looked at only as an investment it would be a remarkably good one. By extending the payment for the grounds over a period of ten years it would bring no burden at all upon the people. Never again can the purchase of ground be so advantageously made as now. Iowa should do business as competent successful business men do. Advantage should be taken of the time and the opportunity. Iowa should announce that she is of age and full-grown. She should step out of the old conditions that hamper and restrain her into the new. The legislature should be unafraid. The people will sustain you. When the work is done they will ever refer to you as the legislature that was far-seeing and wise enough to extend the Capitol Grounds, *** What man is there of you that will lose this the greatest opportunity of his life to render a great public service. Listen not to the voice of selfishness. Tolerate not the "invisible" man. For more than ten years practically all legislation and all political agitation in this country has been against human selfishness. Let it proceed. The rights of all men must be put above the selfishness of a few men. Go forward. Your duty, as it seems to me, is plain.

The great Soldiers and Sailors' Monument, conceived in a holy enthusiasm and carried out with every good intention, has never been officially dedieated. In the published proceedings of the Iowa Department G. A. R. are found these words . 
The Iowa Soldiers and Sailors' Monument, which fitly commemorates the heroic acts of her sons during the greatest epoch of her history as a State, was completed and erected several years ago at a cost of over one hundred and fifty thousand dollars. The artistic merit of both design and execution is universally admitted. The reason for its erection was found in two well defined motives of our people: First, to commemorate the heroic deeds of her citizen soldiers and sailors, and second, to teach the present and all future generations of her people, the lesson of individual patriotism and collective appreciation of that virtue. The location of this beautiful monument is defeating both motives. Dwarfed and overshadowed by our Capitol Building, and hemmed in between a small church building on one side and unfit surroundings on the other, few if any of our people give it more than a passing glance. With such surroundings, the question may well be raised, does this monument in its present location fitly commemorate the deeds of the men for whom its erection was deemed proper? Its chief purpose is being daily defeated. If it were worth while to build this monument at all, it surely is entitled to a location where it can and will be seen by the citizens of this great State, who so generously erected it at great cost. Would it not be just as reasonable to turn the keys in the locks of our other great educational institutions, as to leave this educational factor securely put away from their view in its present location? It has been recently suggested that this monument be removed to the east bank of the Des Moines river, and located on an open square between the two main thoroughfares to the Capitol Building, There it would stand opposite and facing the City Library on the west bank of the river, and adjacent to the block where the new City Hall is being erected, and would rear its shaft in the open, and daily teach its lessons of patriotism and duty to thousands of the people of Iowa.

If the City of Des Moines can be induced, as I believe they can, to deed the State a sufficient plat of ground at the place suggested, I most cordially recommend that this organization use its influence with the next Legislature to pass an act authorizing and directing the removal of the monument to the proposed location. While I believe the cost of the removal will be fully compensated and warranted by the more perfect accomplishment of its purpose, I am persuaded that the project will in effect finance itself. The State must soon provide locations near the Capitol for additional State Buildings, and the vacating of the present site of the monument will release a valuable and suitable site for such purpose, which will more than compensate in value for the cost of removal.

I therefore recommend that this department, through its representatives, approve the suggestion of the removal of the monument 
to the proposed new site, and that it use all honorable efforts to accomplish the same, and I would urge all comrades attending this Encampment to visit both the present and the proposed locations, that you may know personally the advantage of the proposed new site, and that each of you use your influence to bring about this change.

It will be a matter of great personal pride to your present Commander if this suggestion shall be adopted during his incumbency of the office, and I believe my successor will be equally gratified if the accomplishment of this loyal purpose should mark his administration ${ }^{17}$.

At the same Eneampment there was adopted the following:

Resolved, That it is the sense of this Department, in annual Encampment assembled, that all possible honorable efforts should be made to move the monument to the proposed site on the east bank of the Des Moines river, and that each Post in this Department be requested and urged to bring its utmost influence to bear upon the Representative and Senator from its district to bring about the proposed change ${ }^{18}$.

To the Thirty-seventh annual Encampment in session at Muscatine the Commander, quoting this resolution, added these words:

Desiring to carry out the unanimously expressed wish of the Encampment, the attention of the Legislative Committee was called to the matter, and Senator Brown, a member of the committee drafted a bill, amply protecting the State in every way, for the purpose of carrying into effect the removal. Comrade Brown was untiring in his efforts to carry out your wishes, as he was in support of all measures that came before that body in the interest of the Veterans. So successful was he that he secured every vote of the Senate for the measure. The bill then went to the House and was taken charge of by Comrade Zeller, a member of that body. It was late in the session before the bill could be acted on, and some opposition developed in the House Committee on Appropriations to which the bill had been referred. A majority of this committee finally voted for indefinite postponement, with a minority report headed by Comrade Zeller for passage. Both reports were smothered in committee, the chairman refusing to report the bill to the House. Thus the project failed. It was not deemed necessary to have the full

${ }^{17}$ Address of Commander M. McDonald, Iowa Department G. A. R., Des Moines, June, 1910. Journal of Proceedings, S6th Annual Encampment, p. $18-20$.

${ }^{18}$ Resolution, Iowa Department G. A. R., June, 1910. Journal of Proceedings, 36th Annual Encampment, p. 81. 
Legislative Committee in attendance, although they would have responded if notified that their services were needed. Past Commander M. McDonald came on call more than once, and Comrade R. L. Chase, a resident of Des Moines, was continually on the ground, and his efforts were unceasing and valuable. He secured the assistance of the sub-committee of the Greater Des Moines Committee who rendered valuable aid. They are all entitled to your approbation. Senator Brown should receive the especial thanks of this Encampment for his faithful and untiring efforts to carry out your expressed desires. Considering what there was to contend against, most of the State Department being opposed to the removal, it is remarkable that it passed the Senate without a dissenting vote; and I am informed the votes were pledged for its passage in the House provided it came upon the floor. This Department will feel grateful to the Senate, and to those members of the House who pledged their support. Your Department officers had no more interest in the matter than any comrade, but felt it their duty to carry out so far as they could your commands. We failed; but the monument belongs to the State, and if the patriotic people of Iowa are satisfied to allow it to remain in a location that an expert in such matters remarked, "that it was almost an insult to the men it was intended to honor," to allow it to remain in its present location, where all the objects for which it was erected are lost, we ought to be able to stand it. My advice would be to allow all future efforts in that direction to be furthered by those interested, without suggestion from the Grand Army of the Republic ${ }^{19}$.

\section{The Encampment adopted a special resolution as follows:}

Past Department Commander M. McDonald: I wish to offer a resolution for the benefit of the Encampment. It is this:

"Resolved, That the thanks of this Encampment are tendered to Comrade John D. Brown, a Senator in the Thirty-fourth General Assembly, for his untiring efforts to carry out the expressed desires of the Department, and also for his zealous activity for all legislation in the interest of the Veterans."

Commander, in my report a year ago I suggested that the monument that was scarcely seen by a few be removed down to the river bank, where it would be an instructive object for all time to come. The Committee on Commander's Address approved of it, and as I was on the Committee on Legislation we went down to see if we could induce the legislature to appropriate a small sum of money to carry out the request of that Encampment. Through the activity of

${ }^{10}$ Address of Commander H. A. Dyer, Iowa Department G. A. R., Muscatine, June, 1911. Journal of Proceedings, S7th Annual Encampment, 
Comrade Brown it passed the Senate, as you were informed, with no vote against it. It went into the House and we were overjoyed, thinking that our request would be carried out, and that that beautiful monument would stay down there on the river bank where everyone who visited the City of Des Moines could not help but see it, and those that didn't know anything about your valor would ask: "What did that represent?" And they would say: "It represents the valor of the soldiers of Iowa." It was defeated in the House, much to our regret, but I want to say to you, my comrades, being there two or three times during the winter, and seeing the activity of Comrade Brown, there is nothing in the gift of this Department that is too good for that man. That is the reason I want to say that I would like some time to see him rewarded for his generosity.

Comrade T. R. Bickley, Post 69: Second the motion.

Past Department Commander Chas, A. Clarke: Commander, I am glad to second the adoption of the resolution.

The motion to adopt the resolution was then put and duly $\operatorname{arried}^{20}$.

To the Thirty-eighth Annual Encampment the Department Commander said:

Your Commander deems it wise to have your attention again called to the propriety of remedying a great mistake by a former General Assembly, in location of the monument. It should not require a great amount of wisdom to understand that the monument, to be of any educational advantage, should be located where large numbers of people continually pass and repass in its vicinity. And where its public location would protect it from vandals, which is not the case now. All the walks that can be built from any angle leading from the State House will not persuade or cajole people to go out of their way to visit the monument. The walk now under construction is a poor makeshift, suggested by those opposed to the monument's removal. It is a modest suggestion, that it might be well to change the location during the lifetime of a few of the men in whose honor and memory it was erected. It might thereby create sufficient interest among our people to at least dedicate it to the purpose for which it was intended. I leave the matter in your hands for such action as you deem best ${ }^{21}$.

${ }^{20}$ Resolution, Iowa Department G. A. R., June, 1911. Journal of Proceedings, sith Annual Encampment, p. 92-3.

${ }^{21}$ Address of Commander Lot Abraham, Iowa Department G. A. R. Mason City, June, 1912. Journal of Proceedings, S8th Annual Ëncampment, p. $15-16$. 
Among the resolutions adopted is the following:

Resolved, That we heartily endorse that part of the report of Department Commander Abraham concerning the removal of the Iowa Soldiers and Sailors' Monument to a more suitable site in the City of Des Moines ${ }^{22}$.

At the Home-Coming Encampment, in Des Moines, June, 1913, the Thirty-ninth Annual Encampment, the Commander, Capt. John D. Brown, in his annual address, made no reference to the removal of the Soldiers and Sailors' Monument, but at the Camp Fire, Tuesday evening, June 10, 1913, Gen. Grenville M. Dodge, being introduced, spoke as follows:

This year our governor and legislature have performed a great service to the veterans of the State, in enlarging our Capitol Grounds and in giving the proper setting to our Memorial Monument (applause), to our war veterans, and when their work is completed as planned, then those that follow us will look back upon it as one of the most beneficial acts of our State, and give the credit due to our governor and our legislature for their foresight and patriotism. And I hope every comrade while he is here will go up on the Capitol Grounds and look at it as it is today, and then go into the Capitol and see the plan of what it will be in a few years more, and what our monument there will be, that everyone will go to see it, and I hope that Commander Brown, the commander of the G. A. R., will take the proper action for the veterans of Iowa in thanking that legislature and the governor for their great work for us. (Applause.) ${ }^{23}$

In the session of June 12th, the committee on resolutions, consisting of John F. Lacey, Henry H. Rice, A. W. Jaques, Henry Karwarth, E. A. Snyder and M. W. Harmon, reported among other resolutions the following:

Resolved, That we approve of the enlargement of the Capitol Park so as to make the grounds suitable in area and character for the patriotic monuments and memorials already erected and that may hereafter be required by our prosperous commonwealth.

On motion of Major Lacey, adopted ${ }^{24}$.

${ }^{22}$ Resolution, Iowa Department G. A. R., June, 1912. Journal of Proceedings, s8th Annual Encampment, p. 73.

${ }^{2}$ Address of Gen. G. M. Dodge, before Iowa Department G. A. R., Des Moines, June, 1913. Journal of Proceedings, 39th Annual Encampment, p. 124-5.

24Resolution, Iowa Department G. A. R. June, 1913. Journal of Proceedings, 39th Annual Encampment, p. 49. 


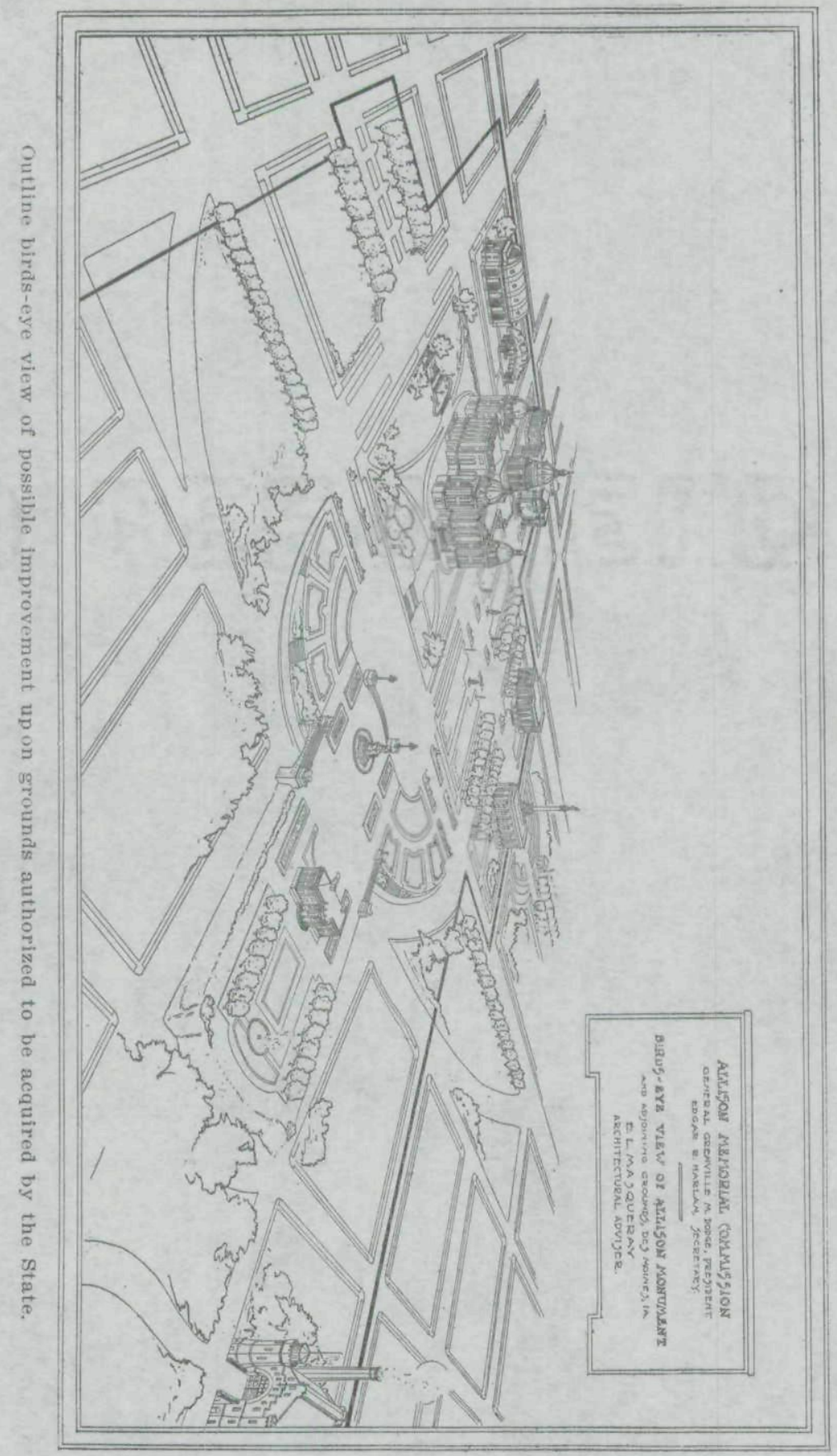


Special attention therefore has been given to the eventual appropriate treatment of our great Soldiers and Sailors' Monument. With grounds ideally_enlarged and treated, with the certainty that the monument will outlast even the Capitol itself, the center of the viewing population upon State property will be eastward of the latter. The mass and height of the monument, the honor in which the men and events it commemorates will forever be held, demand its placement at the intersection of the two principal streets of the enlarged grounds, on the easterly axis of the Capitol. There in the center of such a parade ground as would admit of appropriate patriotic or military occasions, now impossible except in streets, with its four sides clearly visible a thousand feet and more, its grandeur and impressiveness would be incalculably enhanced. The best thought is that this great work, after its ideal placement, shall be regarded as the deliberate artistic expression of the generation producing it and even if any slight deficieney of artistic merit then remain, the whole will be of too sacred a character to be touched by other hands. For the average mind will more and more revere it as the sacrifice which it betokens farther and farther recedes, and as tradition more and more hallows the monument itself.

Out of all this was brought a plan contemplating:

1st. The immediate and correct placement of the Allison Memorial, contracted to be erected in 1915 , at a cost of $\$ 50$,000.00 .

$2 d$. The eventual appropriate placement of our great Soldiers and Sailors' Monument.

$3 d$. The eventual removal of the heating plant to the railroad, relieving the State of the perpetual hauling of coal and ashes and saving the priceless property from the insidious but fatal work of gas and smoke.

4th. Provision for an eventual office and storage room for the Adjutant General, which at present costs the State an annual rental of about $\$ 5,000.00$.

5th. An eventual Executive Mansion, such as has already been provided in Montana, Nevada, Tennessee, Texas, Vir- 
ginia, West Virginia, Nebraska and New York, and is proposed in other states.

6th. Provision for eventual office buildings such as are proposed in California, where ornamental grounds of some thirty-one acres, instead of being impinged upon for a building site, are being protected by the purchase of adjacent grounds at a cost of nearly $\$ 700,000.00$. Many other states already have or contemplate similar equipment in buildings other than their capitols.

7th. Provisions for an eventual Supreme Court building, wherein the priceless records of that tribunal, together with its library and other indispensable auxiliaries may have perpetual growth and constant accessibility; such buildings have been provided in the states of Connecticut, Florida, Illinois and Missouri, and are proposed in other states.

8th. Mr. Masqueray observed and proposed the restoration of the natural scenic value of the capitol site; recognized the probable commemoration in future by monuments and other structures of noted men and events of Iowa; the lack of parade grounds so greatly needed on occasion; the value of an unobstructed view from trunk line trains but a thousand feet away".

There is danger of surrounding areas becoming unsightly, rendering the whole in some sense incomplete. It was, therefore, thought proper to suggest the acquisition of an area in

wThe writer was of the company when Right Hon. James Bryce, The writer was of the company when last visit to our State, inquired what building British Ambassador, on his last visit to our state, isquired "That is the it was whose gilded pinnacle he could see from "is train. "That is the Capitol of Iowa," Governor Carroll responded, "I think our people will improve the surroundings soon." The Ambassador then uttered the substance of his well to which he said:

"The world seems likely to last a long, long time, and we ought to make provision for the future.

"The population of the world goes on constantly increasing and nowhere increasing so fast as in North America.

"A taste for natural beauty is increasing, and as we hope, will go on increasing.

"The places of scenic beauty do not increase, but, on the contrary are in danger of being reduced in number and diminished in quantity, and the danger is always increasing with the accumulation of wealth, owing the danger is of private persons to appropriate these places. There is to the desire of private persons to the masses of the people than to set no better service we can them wide spaces of fine scenery for their delight. about and preserve for them wide spaces of fine scenery for their delight.

"From these propositions I draw the conclusion that it is necessary to save what we have got, and to extend the policy which you have wisely adopted, by acquiring and 
addition to that indispensable for foundations of all eventual structures. Thus the State, through its own work or the work of other owners under its restrictions, would complete the group and grounds in harmony with the State's own standards. Your minds, far more quickly than my own, will comprehend, and I believe, more resolutely sustain this thought. The business mind as easily comprehends the profits inuring to the State in adjacent areas, if any such should be acquired and finally be found unnecessary to the plan of improvement adopted by the State.

Please observe that much of the space on the edge of the proposed enlargement is occupied by schools and churches ${ }^{29}$. You easily foresee that if Iowa abandons haphazard placement and keeps to the best in grounds and architecture, no inferior structure will ever be obtruded by public fund or private benefaction, as witness the quality of recent buildings of Des Moines. By harmonizing with the State's standards others will thus enhance the beauty and value of all adjacent property.

Your profession could scarcely have better revealed its talent for the instant and accurate statement and solution of structural problems than to have produced through one of its members this plan ${ }^{3 \pi}$ for the most eertain, economical, yet desirable correction and completion of the Iowa State Capitol grounds ${ }^{2 s}$.

The selection of some plan, immediate and final, as to the placement of the Allison memorial, having regard for the artistic and economic values of the Capitol and the splendid Soldiers and Sailors' Monument, a plan upon which could be expended not vast funds, but any money, with every care and all skill, was, and is, manifestly obligatory on the present and will be advantageous to all the future. To your

\footnotetext{
${ }^{20}$ See map of proposed improved Capitol grounds and environs, facing p. 96.

${ }^{27}$ See E. L. Masqueray's plan of location of Allison monument, facing p. 104 .

${ }^{28}$ See E. L. Masqueray's birds-eye view of Allison monument and adjoining grounds, facing p. 110.
} 
profession I feel the Allison Commission should and does, in this acknowledgment, pay its respects.

It is with extraordinary satisfaction I say to you that this plan and the law enacting it, when submitted to individual members of your society and of your profession in this country and in Europe, has never failed to evoke expressions of respect and even praise for our governors, for the members of the General Assembly and for General Dodge. It is regarded as the most complete seizure of opportunity, through public law, an American commonwealth has recently made. If this were not deserved, surely technical minds, such as you possess, would long since have warned me. The popular thought has never been at rest upon the random placement of the structures about the Capitol. It is not a question of art or beauty more than of business. No man owning and living in his own house likes to concede the right of careless use or unsightly appearance of adjacent property. The cleanly, sightly, safe and lasting arrangement of permanent property is now mere household taste, not a professional question in Iowa. As for myself, driven rather by hunger than ambition, and led rather by appreciation of things done or diagrammed than by imagination, I can yet say I have had the greatest satisfaction of my whole life in a connection with men, whose tribute to achievement is by way of eternal bronze and stone-whose best work like your own is by fixed principles and once completed is forever done.

Assorted Cargo.- The steamer Pizzaro, lately left St. Louis for the mouth of Kansas river with the following eargo for that point, viz. 20 spinning wheels, twenty looms and their appendages, 300 axes and one hundred ploughs, and last though not least $\$ 10,000$ in specie. This pretty little outfit is said to be for the Iowa and other Indians.-Iowa Sun, Davenport, November 13, 1839. 
Copyright of Annals of Iowa is the property of State of Iowa, by \& through the State Historical Society of Iowa and its content may not be copied or emailed to multiple sites or posted to a listserv without the copyright holder's express written permission. However, users may print, download, or email articles for individual use. 